Article

\title{
An Economical Tandem Multiplex Real-Time PCR Technique for the Detection of a Comprehensive Range of Respiratory Pathogens
}

\author{
Glenys R. Chidlow ${ }^{1,2, *}$, Gerry B. Harnett ${ }^{1}$, Geoffrey R. Shellam ${ }^{2}$ and David W. Smith ${ }^{1,2}$
}

1 Department of Microbiology, Pathwest Laboratory Medicine WA, QEII Medical Centre, Nedlands, WA 6009 Australia

2 School of Biomedical, Biomolecular and Chemical Sciences M502, University of Western Australia, Nedlands, WA 6009 Australia

E-Mails: gerry.harnett@health.wa.gov.au (G-B.H); gshellam@cyllene.uwa.edu.au (G-R.S.); david.smith@health.wa.gov.au (D-W.S)

* Author to whom correspondence should be addressed; E-mail: glenys.chidlow@health.wa.gov.au; Tel.: +61 8 93463260; Fax: +61 893463960

Received: 5 May 2009; in revised form: 2 June 2009 / Accepted: 5 June 2009 /

Published: 8 June 2009

\begin{abstract}
This study used real-time PCR assays to screen small sample volumes for a comprehensive range of 35 respiratory pathogens. Initial thermocycling was limited to 20 cycles to avoid competition for reagents, followed by a secondary real-time multiplex PCR. Supplementary semi-nested human metapneumovirus and picornavirus PCR assays were required to complete the acute respiratory pathogen profile. Potential pathogens were detected in 85 (70\%) of pernasal aspirates collected from 121 children with acute respiratory symptoms. Multiple pathogens were detected in 29 (24\%) of those samples. The tandem multiplex real-time PCR was an efficient method for the rapid detection of multiple pathogens.
\end{abstract}

Keywords: respiratory pathogens; tandem multiplex real-time PCR; mixed infections 


\section{Introduction}

In recent years, improved nucleic acid amplification and detection technology has facilitated the identification of pathogens that had previously proved difficult or impossible to detect using traditional culture or immunofluorescent techniques. The increased use of molecular methods has also resulted in the discovery of novel respiratory pathogens including the human coronaviruses NL63 [1], HKU1[2] and the SARS coronavirus [3], human metapneumovirus [4], human bocavirus [5] and two human polyomaviruses, KI [6] and WU [7]. Despite these advances, there remain a significant proportion of respiratory disease episodes for which a pathogenic agent can not be identified [8, 9].

The aim of this study was to modify real-time PCR assays to facilitate the rapid screening of respiratory samples for a comprehensive range of viral and bacterial pathogens. Standard PCR assays require extraction of RNA and DNA with simultaneous removal of inhibitors of the PCR process from the sample. Multiple extracts from each sample have been required to set up a comprehensive range of PCR assays for respiratory pathogens, and the sample volume available may be insufficient for all of the required tests. Also, previous attempts at multiplex PCR have been limited by competition between different amplification reactions and by the limited number of fluorescent probes able to be monitored in the same tube. A multiplex tandem PCR assay which utilized a two step PCR system consisting of a limited multiplex PCR followed by a single target PCR has been reported [10]. Our study further modified that procedure to include real-time PCR with specific probes in the second step of the assay. It comprised two first round enrichment PCR assays (A and B) containing 27 and 7 primer pairs respectively, and the second step real-time PCR assays containing 1 - 3 primer pairs and specific Taqman probes. The assay detects several adenovirus genotypes, Bordetella species, human bocavirus, Chlamydophila pneumoniae and psittaci, coronaviruses OC43, 229E, HKU1 and NL63, Haemophilus influenzae, influenza viruses A, B and C, Legionella longbeachae and pneumophila, Moraxella catarrhalis, Mycoplasma pneumoniae, parainfluenzaviruses 1 - 4, Pneumocystis jirovecii, KI and WU polyomaviruses, respiratory syncytial virus types A and B, Streptococcus pyogenes and pneumoniae. Supplementary semi-nested human metapneumovirus and picornavirus PCR assays are required to complete the acute respiratory pathogen profile.

This technique facilitates the investigation of a comprehensive range of respiratory pathogens from a single nucleic acid extract and a single reverse transcription reaction. In addition, the ability to amplify multiple targets efficiently aids in the detection of mixed infections.

\section{Results and Discussion}

\subsection{Relative Sensitivity of the tandem multiplex real-time assay}

The sensitivity of the tandem multiplex real-time PCR assay was greater than or equal to that of singleplex real-time or traditional nested PCR assays for the majority of the agents investigated (Table 1). Exceptions included the detection of adenovirus and influenza virus $C$ in the tandem multiplex realtime assay, which were 100-fold and 10-fold less sensitive respectively than the established nested PCR assay. While the adenovirus real-time assay performed similarly in the multiplex and singleplex assays, both had lower sensitivity than the traditional nested assay, suggesting the need to redesign the primers and probes used in the real-time assays. This differed from the influenza virus $C$ assay, where 
the lower sensitivity appeared to be related to the multiplex format, and may therefore necessitate further fine-tuning of the assay.

Table 1. Relative sensitivity of the multiplex tandem real-time PCR compared to single real-time and nested PCR in-house assays.

\begin{tabular}{|c|c|c|c|}
\hline \multirow[b]{2}{*}{ Target DNA/RNA } & \multicolumn{3}{|c|}{ Highest 10 fold dilution detected } \\
\hline & $\begin{array}{l}\text { Multiplex Tandem } \\
\text { real time PCR }\end{array}$ & $\begin{array}{l}\text { Singleplex real } \\
\text { time PCR }\end{array}$ & $\begin{array}{c}\text { Nested PCR } \\
{[11-20]}\end{array}$ \\
\hline Adenovirus (Group B) & $10^{-4}$ & $10^{-4}$ & $10^{-6}$ \\
\hline Bocavirus & $10^{-7}$ & $10^{-7}$ & $\mathrm{NA}^{\mathrm{b}}$ \\
\hline Bordetella pertussis & $10^{-5}$ & $10^{-5}$ & $10^{-5}$ \\
\hline Bordetella holmesii & $10^{-8}$ & $10^{-8}$ & $10^{-8}$ \\
\hline Bordetella parapertussis & $10^{-8}$ & $10^{-7}$ & NA \\
\hline Bordetella bronchoseptica & $10^{-8}$ & $10^{-8}$ & NA \\
\hline Chlamydophila pneumoniae & $10^{-4}$ & $10^{-5}$ & $10^{-4}$ \\
\hline Chlamydophila psittaci & $10^{-6}$ & $10^{-6}$ & $10^{-5}$ \\
\hline Coronavirus 229E & $10^{-8}$ & $10^{-7}$ & $10^{-7}$ \\
\hline Coronavirus HKU1 & $10^{-2}$ & $10^{-2}$ & NA \\
\hline Coronavirus NL63 & $10^{-2}$ & $10^{-3}$ & NA \\
\hline Coronavirus OC43 & $10^{-8}$ & $10^{-9}$ & $10^{-8}$ \\
\hline Haemophilus influenzae & $10^{-5}$ & $10^{-5}$ & NA \\
\hline Influenza virus A H1 ${ }^{\mathrm{a}}$ & $10^{-6}\left(\right.$ Matrix $\left.10^{-6}\right)$ & $10^{-6}$ (Matrix $\left.10^{-6}\right)$ & $10^{-6}$ \\
\hline Influenza virus $\mathrm{A} \mathrm{H}^{\mathrm{a}}$ & $10^{-8}\left(\right.$ Matrix $\left.10^{-6}\right)$ & $10^{-7}$ (Matrix $10^{-6}$ ) & $10^{-6}$ \\
\hline Influenza virus B & $10^{-6}$ & $10^{-7}$ & $10^{-6}$ \\
\hline Influenza virus C & $10^{-4}$ & $10^{-5}$ & $10^{-5}$ \\
\hline Legionella longbeachae & $10^{-4}$ & $10^{-4}$ & $10^{-3}$ \\
\hline Legionella pneumophila & $10^{-5}$ & $10^{-4}$ & $10^{-3}$ \\
\hline Moraxella catarrhalis & $10^{-5}$ & $10^{-5}$ & NA \\
\hline Mycoplasma pneumoniae & $10^{-5}$ & $10^{-5}$ & $10^{-5}$ \\
\hline Parainfluenzavirus 1 & $10^{-8}$ & $10^{-7}$ & $10^{-8}$ \\
\hline Parainfluenzavirus 2 & $10^{-6}$ & $10^{-6}$ & $10^{-6}$ \\
\hline Parainfluenzavirus 3 & $10^{-6}$ & $10^{-5}$ & $10^{-5}$ \\
\hline Parainfluenzavirus 4A & $10^{-6}$ & $10^{-6}$ & NA \\
\hline Parainfluenzavirus 4B & $10^{-3}$ & $10^{-3}$ & NA \\
\hline Pneumocystis jirovecii & $10^{-3}$ & $10^{-2}$ & $10^{-2}$ \\
\hline Polyomavirus KI & $10^{-1}$ & $10^{-1}$ & NA \\
\hline Polyomavirus WU & $10^{-5}$ & $10^{-3}$ & NA \\
\hline RSV A & $10^{-7}$ & $10^{-7}$ & $10^{-7}$ \\
\hline RSV B & $10^{-4}$ & $10^{-4}$ & $10^{-4}$ \\
\hline Streptococcus pyogenes & $10^{-6}$ & $10^{-6}$ & NA \\
\hline Streptococcus pneumoniae & $10^{-3}$ & $10^{-3}$ & NA \\
\hline Equine herpesvirus $4^{\mathrm{C}}$ & $10^{-5}$ & $10^{-5}$ & NA \\
\hline MS-2 RNA coliphage $^{c}$ & $10^{-8}$ & $10^{-7}$ & NA \\
\hline
\end{tabular}

${ }^{\mathrm{a}}$ Separate assays for the HA and matrix gene sequences. Matrix assay results in brackets; ${ }^{\mathrm{b}} \mathrm{NA}=$ Test not available in this laboratory; ${ }^{\mathrm{c}}$ Viruses added to samples to monitor successful nucleic acid extraction, cDNA production and PCR inhibitor removal. 


\subsection{Clinical samples tested in the tandem multiplex real-time assay}

Pernasal aspirates from 121 hospitalized children aged between 3 days and 16 years (mean $=20$ months old, median $=7$ months old) collected from July to September 2006 were tested in the tandem multiplex real-time PCR assay and the results are presented in Table 2. Respiratory pathogens were detected in 85 samples (71\%) and multiple pathogens were detected in 29 of those 85 samples (34\%). This detection rate excludes samples where Moraxella catarrhalis and/or Streptococcus pneumoniae were detected, as the significance of the detection of these agents in pernasal aspirates using PCR amplification techniques remains doubtful [21-23]. Further studies are under way to gather more information about asymptomatic nasopharyngeal carriage rates for viral and bacterial pathogens.

Respiratory syncytial virus (RSV) was the most common pathogen and was detected in 41 samples. For 21 of those samples, at least one, and up to three other respiratory agents, including human rhinovirus, human bocavirus, KI and WU polyomaviruses, human coronaviruses, parainfluenzavirus and group A streptococcus, were also detected. Rhinoviruses were the next most commonly detected (37 samples) and again, multiple agents were commonly detected (17 samples) and included RSV, human coronaviruses, human bocavirus, parainfluenzavirus, adenovirus, KI and WU polyomaviruses and group A streptococcus. Other pathogens detected included influenza virus type B, human metapneumovirus and Pneumocystis jirovecii.

The tandem multiplex real-time assay failed to detect pathogens that had previously been detected on initial routine testing in six samples. The agents were rhinovirus (2), parainfluenza type 2, parainfluenza type 3, human metapneumovirus and influenza B. Repeat testing of samples indicated that for the two parainfluenzavirus failures there had been a slight reduction in nucleic acid extraction sensitivity due to the deterioration of carrier RNA used in the extraction process, and once that was overcome the samples performed as expected in the multiplex tandem assay. There was insufficient sample from the remaining four patients to complete similar further investigations. Other samples with discrepant results were due to the absence of specific primers and probes to those agents in this tandem multiplex real-time assay. They included non-group B adenovirus (9), CMV (3) and non-serogroup b Haemophilus influenzae (2).

The tandem multiplex real-time assay detected respiratory pathogens in 18 specimens for which no agent had previously been detected. The agents included RSV (4), rhinovirus (7), human bocavirus (3), coronaviruses (3), and parainfluenzavirus. A further 25 specimens had multiple agents detected in the tandem multiplex real-time assay compared to the original test result. These additional detections were mostly due to the comprehensive range of respiratory pathogens detected by the tandem multiplex real-time assay compared to the selective range of tests originally performed as requested by the clinician. Positive results were confirmed by repeat testing, and no-template controls were included after every fifth sample during the extraction and PCR process to detect contamination events.

The samples in this study were collected between June and September 2006, which represents midlate winter and early spring months, which have typically been the peak respiratory virus detection months in the temperate zones of Western Australia. Despite the comprehensive range of agents detected by the assay described in this study, 35 (29\%) samples still failed to yield a positive result. Some of these may be due to suboptimal specimen types for some viruses; poor collection, transport or storage conditions; samples collected too late in the time course of infection; or non-infectious causes 
of respiratory symptoms. However, it may also indicate possible infection with as yet unknown pathogens.

The significance of the recently described KI and WU polyomaviruses as pathogens remains to be established since, although there has been an association with the respiratory tract [24], a recent report found no association between polyomavirus infection and respiratory disease [25]. In our study KI and WU polyoma viruses were each detected in 4 different samples (3\%), but always in combination with another virus, including RSV, adenovirus, rhinovirus, bocavirus, coronavirus and parainfluenzavirus.

The widespread and increasing use of molecular detection techniques has led to reports of multiple pathogenic agents detected in single samples [26-28]. This study supports those findings with two agents detected in 19 (16\%) samples, and three or more agents detected in 10 (8\%) samples (Table 2). No data was available to determine whether this may have altered the severity of illness. Some studies have reported more severe clinical presentation in the presence of mixed infection $[9,29,30]$ while others have reported no significant greater disease severity in dual respiratory infection [31].

It has been reported that the detection of multiple agents in a multiplex PCR assay was severely compromised when the ratio of target materials in the sample exceeded 100:1 [32]. We also found similar inhibition in a traditional multiplex which was less evident in the tandem multiplex real-time assay (data not shown). In practice, the tandem multiplex real-time assay detected multiple pathogens in 29/121 (24\%) samples.

Table 2. Agents detected in PNA samples from 121 hospitalized children.

\begin{tabular}{|l|l|l|}
\hline $\begin{array}{l}\text { Number of } \\
\text { samples }\end{array}$ & Original reported result $\dagger$ & $\begin{array}{l}\text { Tandem multiplex real-time PCR plus } \\
\text { supplementary picornavirus and } \\
\text { metapneumovirus semi-nested PCR result }\end{array}$ \\
\hline 12 & RSV & RSV A (4), RSV B (8) \\
1 & RSV, PIV-1 & RSV B, PIV-1 \\
12 & Human rhinovirus (HRV) & HRV, PIV-1 \\
1 & HRV, PIV-1 & Influenza virus B \\
4 & Influenza virus B & PIV-1 \\
1 & PIV-1 & PIV-3 \\
2 & PIV-3 & Human metapneumovirus (hMPV) \\
1 & Human metapneumovirus & Neg \\
31 & Neg & RSV A (2), RSV B (2) \\
4 & Neg & HRV \\
7 & Neg & HBoV \\
3 & Neg & HRV, KI polyomavirus \\
1 & Neg & HCoVHKU1 \\
1 & Neg & HCoVNL63, Pneum jirovecii, WU polyomavirus \\
1 & Neg & HCoVNL63 \\
1 & Neg & PIV-3 \\
1 & Neg & RSV A, HRV \\
4 & RSV & RSV B, HRV \\
1 & RSV & RSV A, HBoV, GAS \\
2 & RSV & RSV A, HBoV \\
1 & RSV & \\
\hline
\end{tabular}


Table 2. Cont.

\begin{tabular}{|l|l|l|}
\hline 1 & RSV & RSV B, HBoV \\
2 & RSV & RSV A, HRV, KI polyomavirus \\
2 & RSV & RSV B, HCoVHKU1 \\
1 & HRV & HRV, HCoVNL63 \\
1 & HRV & HRV, HBoV \\
1 & AdV & HRV, AdV \\
1 & Influenza virus B & Influenza virus B, HCoVHKU1 \\
1 & RSV, AdV & RSV A, HRV, HBoV, GAS \\
1 & RSV, AdV & RSV B, HRV, HBoV, GAS \\
1 & RSV, AdV & RSV B, HRV, HBoV, HCoVNL63 \\
1 & RSV, AdV & RSV A, GAS \\
2 & RSV, AdV & RSV B \\
1 & RSV, AdV & RSV A, HRV, KI polyomavirus \\
1 & RSV, AdV & RSV B, HBoV \\
1 & RSV, Haemophilus influenzae & RSV A \\
1 & AdV & WU polyomavirus \\
1 & CMV & HRV, WU polyomavirus \\
1 & CMV & HRV \\
1 & CMV & hMPV \\
1 & Haemophilus influenzae & Neg \\
1 & RSV, PIV-2 & RSV B \\
1 & RSV, PIV-3 & RSV A, HBoV, HCoVHKU1,WU polyomavirus \\
1 & Influenza virus B & HRV \\
2 & hMPV & Neg \\
1 & & Neg \\
\hline
\end{tabular}

† Original reported result for tests requested by clinician, performed as nested PCR assays except CMV (real-time PCR) and Haemophilus influenzae (bacterial culture).

\subsection{Economies delivered by the tandem multiplex real-time PCR format}

Traditionally, testing for a comprehensive range of respiratory pathogens has necessitated multiple PCR assays, immunofluorescence or multiple cell culture assays to be performed on each sample. Considerable specimen volume is required to produce sufficient nucleic acid extracts for multiple PCR assays and, since many respiratory viruses have an RNA genome, multiple reverse transcription reactions are required. Multiple extraction and reverse transcription reactions significantly increase the cost of the assays. There have been recent reports of limited multiplex PCR assays [26,33-36] and realtime multiplex PCR assays for the detection of respiratory viruses and bacteria [37-39]. Immunofluorescent antigen detection tests may be used but require a substantial volume of sample, as well as needing an adequate cellular content. Cell culture techniques require considerable sample volume, a range of different cell lines, and the means for detecting and identifying those agents that are successfully cultivated. Many of the recently described novel viruses including human metapneumovirus, coronaviruses, human bocavirus and some rhinoviruses are difficult or impossible to cultivate in cell cultures [26-28,40,41]. 
A multiplex tandem PCR was recently described for gene expression profiling [10]. The first enrichment reverse transcription PCR contained up to 72 primer pairs, and the individual second PCR assays utilized SYBR Green detection of products. We have modified that technique to include specific Taqman probes in the second PCR assay to permit specific real-time detection of the PCR product. The two enrichment PCR mixes contain 27 and 7 primer pairs, and the real-time PCR mixes contain 1-3 primer pairs with their corresponding fluorophore-labelled probes (Table 3). The enrichment PCR was limited to 20 amplification cycles to reduce amplification competition between targets, and the dilution of that enrichment PCR product prior to addition to the real-time PCR mix, limited non-specific product formation and carry-over primer competition in the secondary PCR assay [10].

The use of nucleic acid extraction and liquid handling robots streamlined this tandem multiplex real-time assay. The nucleic acid extracted from the specimens and controls was eluted into tubes in a 96-well format. The enrichment PCR and dilutions were all performed in 96-well plates, and robots used to transfer diluted enrichment PCR products to the 100-tube discs preloaded with real-time PCR reaction mixes (Genedisc-100, Corbett Life Science, Australia). Since the initial cycling step was limited to 20 cycles the transfer of those products had a reduced the risk of contamination compared with a traditional nested assay.

The addition of standardized amounts of equine herpesvirus and MS2 RNA coliphage to the digest buffer supplied in the nucleic acid extraction kit, served as a control for the DNA and RNA extraction process, the removal of inhibitors to the cDNA production and PCR amplification processes, and the successful completion of the cDNA procedure. CT values in the specific real-time PCR assays for these internal controls were monitored to avoid false-negative reports.

This tandem multiplex real-time PCR assay, in combination with the semi-nested picornavirus and human metapneumovirus PCR assays, tests for 35 respiratory agents from a sample volume of $180 \mu \mathrm{L}$ compared to $720 \mu \mathrm{L}$ required for the individual assays. A single sample extraction and three reverse transcription reactions are required for the tandem multiplex real-time assay, compared to four extractions and 17 reverse transcription reactions for the individual assays. In our laboratory the consumable costs are approximately AUD 67 for the individual assays compared to AUD 17 for the tandem multiplex real-time assay. Further work is planned to incorporate the picornavirus and human metapneumovirus assays into the tandem multiplex real-time PCR assay, but so far we have been unable to design or use published real-time PCR primers and probes that detect all types of these viruses with the same sensitivity as our nested assays.

The multiplex tandem PCR assay described has the potential to test for a much larger number of infectious agents, or to look for multiple targets in single agents. In this study, enrichment PCR-B contained only seven primer pairs, so it will be possible to add extra primers to detect a broader range of known or newly described agents. For example, it is planned to include primers directed against adenoviruses other than group $\mathrm{B}$, and a broader range of Haemophilus influenzae serogroups. Similarly, continued experience with the assay and further assessment of the role of novel agents in respiratory disease, may lead to the removal of some primer pairs from the PCR mixes.

This test also allows the flexibility to determine which of the organisms included in the enrichment PCR are to be included in the second round, usually with the aim of restricting the initial testing to the 
most common pathogens. If this is negative, tests for other organisms included in the enrichment PCR can then be performed without the need for more sample or further cDNA synthesis.

\section{Materials and Methods}

\subsection{Nucleic acid extraction}

Bacterial and viral RNA and DNA was extracted from respiratory specimens including nose swabs, throat swabs, pernasal aspirates and sputum samples, using a modified liquid sample protocol with the $\mathrm{X}$-tractor Gene instrument (Corbett Life Science, Australia). Standardized doses of equine herpesvirus type 4 (EHV4) and MS2 RNA coliphage (MS2) were added to the lysis buffer supplied with the kit to monitor the efficiency of sample extraction, removal of reverse transcription and PCR inhibitors, and cDNA production [42, 43]. The CT values expected for the EHV4 and MS2 assays were between 15 and 20, and samples with CT values greater than 27 were retested.

\subsection{Primer and Probe Design}

Taqman primers and probes listed in Table 3, were designed in-house using Primer Express software (Applied Biosystems, USA), with the exception of those for the influenza virus A matrix gene [44]. The letter in the final column of the table indicates which of the enrichment PCR mixes contained the primers, and the number indicates which of the real-time PCR mixes contained the primers and probes. At present, not all of the real-time PCR mixes contain uniquely specific fluorophore-labelled probes, so further confirmation of some positive results is required. For example, in the parainfluenza mixes the types 1 and 2 probes both have FAM labels and the type 4A and 4B probes both have VIC labels, so individual real-time PCRs may be performed from the original enrichment PCR material if further typing is required. The mixes were prepared in large volumes, stored in single use aliquots at $-80^{\circ} \mathrm{C}$, and batches were quality tested prior to use.

Table 3. Primers and probes included in the multiplex tandem real time PCR assay.

\begin{tabular}{|c|c|c|c|c|}
\hline $\begin{array}{l}\text { Target (Abbreviation) } \\
\text { Gene target }\end{array}$ & $\begin{array}{l}\text { Primer or } \\
\text { Probe name }\end{array}$ & Sequence 5’-3’ & $\begin{array}{l}\text { Size } \\
\text { (bp) }\end{array}$ & $\begin{array}{l}\text { PCR } \\
\text { mix }^{a}\end{array}$ \\
\hline $\begin{array}{l}\text { Adenovirus (AdV) } \\
\text { (Group B) } \\
\text { Hexon gene }\end{array}$ & $\begin{array}{l}\text { ADB-F } \\
\text { ADB-R } \\
\text { ADBProbe1 } \\
\text { ADBProbe2 }\end{array}$ & $\begin{array}{l}\text { GACAGGATGCTTCGGAGTACCT } \\
\text { TTTCTAAACTTKTTYCCCAYAYTGAA } \\
\text { 6FAM-CACCAGACCCGGACT-MGBNFQ } \\
\text { 6FAM-CTGCACCAGACCCGG-MGBNFQ }\end{array}$ & 91 & A-2 \\
\hline $\begin{array}{l}\text { Bocavirus (HBoV) } \\
\text { VP1 }\end{array}$ & $\begin{array}{l}\text { BOCA-F } \\
\text { BOCA-R } \\
\text { BocaProbe }\end{array}$ & $\begin{array}{l}\text { TGGGCCATTTAATCCACTTGA } \\
\text { AATTGAGCAGCGCGATCAG } \\
\text { VIC-ATTTACAGGTTCACCGTT-MGBNFQ }\end{array}$ & 63 & A-2 \\
\hline $\begin{array}{l}\text { Bordetella species } \\
\text { Insertion element } \\
\text { B parapertussis \& } \\
\text { B bronchoseptica } \\
\text { Pertussis toxin } \\
\end{array}$ & $\begin{array}{l}\text { IS481-F } \\
\text { IS481-R } \\
\text { IS481 Probe } \\
\text { BPA-F } \\
\text { BPA-R } \\
\text { BPA Probe }\end{array}$ & $\begin{array}{l}\text { CGGATGAACACCCATAAGCA } \\
\text { AACTTGATGGGCGATCAATTG } \\
\text { 6FAM-TCCTACGTCGACTCGAA-MGBNFQ } \\
\text { ATCCCGCTACTGTAATCCAA } \\
\text { GGTACCATCGTGCGACTTT } \\
\text { 6FAM-CACGGCGCAAAC-MGBNFQ }\end{array}$ & 81 & A-5 \\
\hline $\begin{array}{l}\text { Chlamydophila } \\
\text { pneumoniae } \\
\text { MOMP }\end{array}$ & $\begin{array}{l}\text { CPD-F } \\
\text { CPD-R } \\
\text { CPD Probe }\end{array}$ & $\begin{array}{l}\text { GAAGGGTTCCATGCAGTTAAGTTT } \\
\text { TGATGCTGATAACATCCGCATT } \\
\text { VIC-CTCAGCCAAARCTACCTACAGMGBNFQ }\end{array}$ & 75 & A-3 \\
\hline
\end{tabular}


Table 3. Cont.

\begin{tabular}{|c|c|c|c|c|}
\hline $\begin{array}{l}\text { Chlamydophila } \\
\text { psittaci } \\
\text { MOMP }\end{array}$ & $\begin{array}{l}\text { CPSITT-F } \\
\text { CPSITT-R } \\
\text { CPsittProbe }\end{array}$ & $\begin{array}{l}\text { CTCCTTACAAGCCTTGCCTGTAG } \\
\text { CCCACATAGTGCCATCGATTAA } \\
\text { CY5.5C+CCAGC+TGAA+C+CAAG+TT-BHQ3 } \\
\text { (LNA) }\end{array}$ & 68 & A-2 \\
\hline $\begin{array}{l}\text { Coronavirus 229E } \\
\text { (HCoV229E) } \\
\text { Nucleocapsid }\end{array}$ & $\begin{array}{l}\text { 229E-F } \\
\text { 229E-R } \\
\text { 229E Probe }\end{array}$ & $\begin{array}{l}\text { CTGCCAAGAGTCTTGCTCGTT } \\
\text { TCTTTTCCACCGTGGCTTTT } \\
\text { VIC-AGAACAAAAGCATGAAATG-MGBFQ }\end{array}$ & 80 & A-6 \\
\hline $\begin{array}{l}\text { Coronavirus HKU1 } \\
\text { (HCoVHKU1) } \\
\text { ORF 1a/b }\end{array}$ & $\begin{array}{l}\text { HKCOR-F } \\
\text { HKCOR-R } \\
\text { HKCoProbe }\end{array}$ & $\begin{array}{l}\text { CCCGCAAACATGAATTTTGTT } \\
\text { CATTCATTCGCAAGGCGATA } \\
\text { 6FAM-AATCTATCACCATGTGAA-MGBNFQ }\end{array}$ & 61 & A-7 \\
\hline $\begin{array}{l}\text { Coronavirus NL63 } \\
\text { (HCoVNL63) } \\
\text { Nucleocapsid } \\
\end{array}$ & $\begin{array}{l}\text { NL63-F } \\
\text { NL63-R } \\
\text { NL63 Probe }\end{array}$ & $\begin{array}{l}\text { AACCTCGTTGGAAGCGTGTT } \\
\text { CGAGGACCAAAGCACTGAATAA } \\
\text { VIC-ATTTTCCTCTCTGGTAG-MGBNFQ }\end{array}$ & 61 & A-7 \\
\hline $\begin{array}{l}\text { Coronavirus OC43 } \\
\text { (HCoVOC43) } \\
\text { Nucleocapsid }\end{array}$ & $\begin{array}{l}\text { OC43-F } \\
\text { OC43-R } \\
\text { OC43 Probe }\end{array}$ & $\begin{array}{l}\text { GACATGGCTGATCAAATTGCTAGT } \\
\text { GCTGAGGTTTAGTGGCATCCTT } \\
\text { 6FAM-TCTGGCAAAACTTGG-MGBNFQ }\end{array}$ & 67 & A-6 \\
\hline $\begin{array}{l}\text { Equine herpesvirus } 4 \\
\text { (EHV) } \\
\text { Glycoprotein gB }\end{array}$ & $\begin{array}{l}\text { EHV-F } \\
\text { EHV-R } \\
\text { EHV Probe }\end{array}$ & $\begin{array}{l}\text { GATGACACTAGCGACTTCGA } \\
\text { CAGGGCAGAAACCATAGACA } \\
\text { 6FAM-TTTCGCGTGCCTCCTCCAG-BHQ1 }\end{array}$ & 81 & B-17 \\
\hline $\begin{array}{l}\text { Haemophilus } \\
\text { influenzae Serotype b } \\
\text { capsulation locus }\end{array}$ & $\begin{array}{l}\text { HINF-F } \\
\text { HINF-R } \\
\text { HINF Probe }\end{array}$ & $\begin{array}{l}\text { AGAAGTTTTACTGATGATATGGGTACATCT } \\
\text { GCTCGAAGAATGAGAAGTTTTGTG } \\
\text { 6FAM-TTCGCCATAACTTCATCT-MGBNFQ }\end{array}$ & 79 & B-14 \\
\hline $\begin{array}{l}\text { Influenza virus A } \\
\text { Matrix } \\
\text { [44] }\end{array}$ & $\begin{array}{l}\text { FA-MATF } \\
\text { FA-MATR } \\
\text { FA Probe }\end{array}$ & $\begin{array}{l}\text { CTTCTAACCGAGGTCGAAACGTA } \\
\text { GGTGACAGGATTGGTCTTGTCTTTA } \\
\text { CALOTCAGGCCCCCTCAAAGCCGAGBHQ1 }\end{array}$ & 155 & A-4 \\
\hline $\begin{array}{l}\text { Influenza virus A H3 } \\
\text { haemagglutinin }\end{array}$ & $\begin{array}{l}\text { H3N2-F } \\
\text { H3N2-R } \\
\text { H3HAProbe }\end{array}$ & $\begin{array}{l}\text { ACGAAGTGGGAAAAGCTCAATAAT } \\
\text { GGAGTGATGCATTCAGAATTGC } \\
\text { 6FAM-ATGCACCCATTGGC-MGBNFQ }\end{array}$ & 72 & A-11 \\
\hline $\begin{array}{l}\text { Influenza virus A H1 } \\
\text { haemagglutinin }\end{array}$ & $\begin{array}{l}\text { H1N1-F } \\
\text { H1N1-R } \\
\text { H1HAProbe }\end{array}$ & $\begin{array}{l}\text { AAGCTCATGGCCCAACCA } \\
\text { CCATTATGGGAGCATGATGCT } \\
\text { 6FAM-ATACTCCGGTCACGGT-MGBNFQ }\end{array}$ & 57 & A-12 \\
\hline $\begin{array}{l}\text { Influenza virus B } \\
\text { matrix }\end{array}$ & $\begin{array}{l}\text { FBMAT-F } \\
\text { FBMAT-R } \\
\text { FB Probe }\end{array}$ & $\begin{array}{l}\text { TGCCTACCTGCTTTMMYTRACA } \\
\text { CCRAACCAACARTGTAATTTTTCTG } \\
\text { 6FAM-TGCTTTGCCTTCTCCA-MGBNFQ }\end{array}$ & 75 & A-4 \\
\hline $\begin{array}{l}\text { Influenza virus C } \\
\text { NS1 }\end{array}$ & $\begin{array}{l}\text { FLUC-F } \\
\text { FLUC-R } \\
\text { FLUCProbe }\end{array}$ & $\begin{array}{l}\text { CCTAGAACITGGGAAGAKGCR } \\
\text { GCAGAATCGTYCCGTTGAA } \\
\text { 6FAM-AGRAGCTCACMAYCTTTT-MGBNFQ }\end{array}$ & 61 & A-4 \\
\hline $\begin{array}{l}\text { Legionella } \\
\text { longbeachae } \\
\text { mip gene }\end{array}$ & $\begin{array}{l}\text { LLong-F } \\
\text { LLong-R } \\
\text { LLongProbe }\end{array}$ & $\begin{array}{l}\text { TGGTCACTGCGGCCATTA } \\
\text { CATCAGTTGCAGCCATTGCT } \\
\text { 6FAM-ACATTGCCAAACCCA-MGBNFQ }\end{array}$ & 58 & A-3 \\
\hline $\begin{array}{l}\text { Legionella } \\
\text { pneumophila } \\
\text { mip gene }\end{array}$ & $\begin{array}{l}\text { LPN-F } \\
\text { LPN-R } \\
\text { LPN Probe }\end{array}$ & $\begin{array}{l}\text { CAATGGCTAAAGGCATGCAA } \\
\text { TGCTGTTCGGTTAAAGCCAAT } \\
\text { 6FAM-AGCGCCACTCATAGCGT-MGBNFQ }\end{array}$ & 61 & A-3 \\
\hline $\begin{array}{l}\text { Moraxella } \\
\text { catarrhalis } \\
\text { OMP }\end{array}$ & $\begin{array}{l}\text { MOR-F } \\
\text { MOR-R } \\
\text { MOR Probe } \\
\end{array}$ & $\begin{array}{l}\text { TCGCCAAGGTGCRAAAATTAA } \\
\text { GCCGTGCTTTCGTCTTTTTC } \\
\text { VIC-ACCAATGTTGTTACCTTRCG-MGBNFQ } \\
\end{array}$ & 63 & B-14 \\
\hline $\begin{array}{l}\text { MS-2 RNA } \\
\text { coliphage } \\
\text { Coat protein }\end{array}$ & $\begin{array}{l}\text { MS2-F } \\
\text { MS2-R } \\
\text { MS2 Probe }\end{array}$ & $\begin{array}{l}\text { GTCGACAATGGCGGAACTG } \\
\text { TTCAGCGACCCCGTTAGC } \\
\text { CALOACGTGACTGTCGCCCCAAGCAACTT-BHQ1 }\end{array}$ & $\begin{array}{l}66 / \\
74\end{array}$ & A-1 \\
\hline $\begin{array}{l}\text { Mycoplasma } \\
\text { pneumoniae } \\
\text { Cytadhesion P1 }\end{array}$ & $\begin{array}{l}\text { MPN-F } \\
\text { MPN-R } \\
\text { MPN Probe }\end{array}$ & $\begin{array}{l}\text { AAGTACCACCACGACGCTCAA } \\
\text { TCGTCAGGGCGGGTGTAG } \\
\text { 6FAM-CGCCAGCAATTTA-MGBNFQ }\end{array}$ & 54 & A-10 \\
\hline
\end{tabular}


Table 3. Cont.

\begin{tabular}{|c|c|c|c|c|}
\hline $\begin{array}{l}\text { Parainfluenzavirus } \\
\text { (PIV) } \\
\text { Nucleoprotein }\end{array}$ & $\begin{array}{l}\text { PF1-F } \\
\text { PF1-R } \\
\text { PF1 Probe } \\
\text { PF2-F } \\
\text { PF2-R } \\
\text { PF2 Probe } \\
\text { PF3-F } \\
\text { PF3-R } \\
\text { PF3 Probe } \\
\text { PF4A-F } \\
\text { PF4A-R } \\
\text { PF4A Probe } \\
\text { PF4B-F } \\
\text { PF4B-R } \\
\text { PF4B Probe }\end{array}$ & $\begin{array}{l}\text { GCAAAGAGARAATGCRGATCTAG } \\
\text { AGCTCCGAGACATGCAGGAT } \\
\text { 6FAMTCCATATGTCTGAAGCAATMGBNFQ } \\
\text { ATTCCAGATGCTCGATCAACTATG } \\
\text { TCYTCAGCTAATGCTTCRAARGC } \\
\text { 6FAM-AGCACYTCTCCTCTGG-MGBNFQ } \\
\text { CGCGCTCCWTTYATCTGTATC } \\
\text { TTGCCTGGTGCGAACTCA } \\
\text { VIC-TCAGAGATCCYATACATG-MGBNFQ } \\
\text { CACACACACAATGGGCACAA } \\
\text { GCGTATTTGGTGAGAGTTTTGAGTT } \\
\text { VIC-CAATCCCACACTACAAC-MGBNFQ } \\
\text { CGCACACATACAATGAAAGCAA } \\
\text { TGGCGGGATTTCTGAGTTG } \\
\text { VIC-CACTCCTGTCCCACATC-MGBNFQ }\end{array}$ & 65 & A-8 \\
\hline $\begin{array}{l}\text { Pneumocyctis } \\
\text { jirovecii } \\
\text { 5S rRNA }\end{array}$ & $\begin{array}{l}\text { PN-F } \\
\text { PN-R } \\
\text { PN Probe }\end{array}$ & $\begin{array}{l}\text { CCATACCTCAGAGAATATACCGTATCC } \\
\text { TACTGACGACGCCCTTCAGA } \\
\text { 6FAM-TRACTTCGCAGATCG-MGBNFQ }\end{array}$ & 69 & A-10 \\
\hline $\begin{array}{l}\text { Polyomavirus } \\
\text { VP1 }\end{array}$ & $\begin{array}{l}\text { KI-F } \\
\text { KI-R } \\
\text { KI Probe } \\
\text { WU-F } \\
\text { WU-R } \\
\text { WU Probe }\end{array}$ & $\begin{array}{l}\text { GGTTCTGGAGCTGCCATAGC } \\
\text { AAGAAGTGCAGCTCCCTCTGTT } \\
\text { 6FAM-CCAAGGGCAGCTAAGCCTTCACCA-BHQ1 } \\
\text { AGTCAACCCACAAGAGTGCAAA } \\
\text { CAGCACGTCTACCCCTCCTTT } \\
\text { VIC-CCTTCCAAAACAAGTCAG-MGBNFQ }\end{array}$ & 77 & B-16 \\
\hline $\begin{array}{l}\text { Respiratory syncytial } \\
\text { virus A (RSV A) } \\
\text { Nucleoprotein } \\
\text { Respiratory syncytial } \\
\text { virus B (RSV B) } \\
\text { Nucleoprotein } \\
\end{array}$ & $\begin{array}{l}\text { RSVA-F } \\
\text { RSVA-R } \\
\text { RSVAProbe } \\
\text { RSVB-F } \\
\text { RSVB-R } \\
\text { RSVBProbe }\end{array}$ & $\begin{array}{l}\text { CAACTTCTGTCATCCAGCAAA } \\
\text { TGCACATCATAATTAGGAGTATCAAT } \\
\text { 6FAM-CACCATCCAACGGAGC-MGBNFQ } \\
\text { ATTCAACGTAGTACAGGAGATAATA } \\
\text { CCACATAGTTTGTTTAGGTGTTT } \\
\text { VIC-TGACACTCCCAATTAT-MGBNFQ }\end{array}$ & 74 & A-5 \\
\hline $\begin{array}{l}\text { Group A } \\
\text { Streptococcus } \\
\text { speB gene }\end{array}$ & $\begin{array}{l}\text { STAspeB-F } \\
\text { STAspeB-R } \\
\text { STspBProbe }\end{array}$ & $\begin{array}{l}\text { CTAAACCCTTCAGCTCTTGGTACTG } \\
\text { TTGATGCCTACAACAGCACTTTG } \\
\text { 6FAM-CGGCGCAGGCGGCTTCAAC-BHQ1 }\end{array}$ & 77 & B-11 \\
\hline $\begin{array}{l}\text { Streptococcus } \\
\text { pneumoniae } \\
\text { Pneumolysin gene }\end{array}$ & $\begin{array}{l}\text { Pneum-F } \\
\text { Pneum-R } \\
\text { Pn Probe }\end{array}$ & $\begin{array}{l}\text { CCACTCTTCTTGCGGTTGATC } \\
\text { GCCAAACCAGGCAAATCAAT } \\
\text { 6FAM-TGCTCCGATGACTTATA-MGBNFQ }\end{array}$ & 61 & B-14 \\
\hline
\end{tabular}

${ }^{a}$ The letter indicates in which of the two enrichment PCR assays the primers are included, and the number indicates in which of 16 real time PCR mixes the primers and corresponding probes may be found.

\section{3. $P C R$}

Enrichment PCR assays A \& B, were set up in 96-well plates (Axygen Scientific, USA) using a liquid handling robot (CAS1200 Corbett Life Science, Australia) to add PCR reaction mix and the sample or control nucleic acid extracts. The first enrichment PCR used the Superscript III Platinum One-step RT-PCR system (Invitrogen, USA). The $50 \mu \mathrm{L}$ reaction mix A contained 54 primers each at 0.2-0.3 $\mu \mathrm{M}, 10$ units RNaseOUT (Invitrogen, USA), 10mM DTT (Sigma, USA), 0.75 $\mu \mathrm{L}$ Superscript III RT/Platinum Taq Mix, 1.25unit iStar Taq DNA polymerase (Intron Biotechnology, USA), 1.5\% DMSO (Sigma, USA), and $8 \mu \mathrm{L}$ RNA/DNA specimen extract. The cycling conditions were $30 \mathrm{~min}$ at 
$50{ }^{\circ} \mathrm{C}, 5 \mathrm{~min}$ at $95^{\circ} \mathrm{C}$, followed by 20 cycles of $94^{\circ} \mathrm{C}$ for $30 \mathrm{sec}, 50^{\circ} \mathrm{C}$ for $30 \mathrm{sec}$, and $68{ }^{\circ} \mathrm{C}$ for $45 \mathrm{sec}$, on an ABI 2700 thermal cycler (Applied Biosystems, USA). The $50 \mu \mathrm{L}$ reaction mix B contained 14 primers each at $0.2 \mu \mathrm{M}, 4 \mathrm{mM} \mathrm{MgCl}_{2}$ (Applied Biosystems, USA), $200 \mu \mathrm{M}$ dNTP (Fisher Biotec, Australia), 0.01\% bovine serum albumin (Sigma, USA), 1.5 units Amplitaq Gold DNA polymerase (Applied Biosystems, USA) and $8 \mu \mathrm{L}$ RNA/DNA specimen extract. Cycling conditions were $95^{\circ} \mathrm{C}$ for $10 \mathrm{~min}$, followed by 20 cycles of $95^{\circ} \mathrm{C}$ for $30 \mathrm{sec}, 50^{\circ} \mathrm{C}$ for $30 \mathrm{sec}$ and $72^{\circ} \mathrm{C}$ for $45 \mathrm{sec}$.

The initial enrichment PCR products were diluted 1:10 in PCR grade water, and a 1.0 $\mu \mathrm{L}$ sample was added to a $20 \mu \mathrm{L}$ reaction mix in 100 tube rings (Gendisc-100, Corbett Life Science, Australia) containing 2-6 oligonucleotide primers at $0.2 \mu \mathrm{M}, 0.2 \mu \mathrm{M}$ Taqman probes, $6 \mathrm{mM} \mathrm{MgCl}_{2}, 0.4 \mathrm{mM}$ dNTP, and 1.0 unit of i-StarTaq DNA polymerase. The dilution and product transfer procedures were performed by a liquid handling robot (CAS1200 Corbett Life Science, Australia). The reaction was cycled on a Rotorgene 6000 real time thermocycler (Corbett Life Science, Australia). The cycling conditions were $94{ }^{\circ} \mathrm{C}$ for $2 \mathrm{~min}$, followed by 35 cycles of $94{ }^{\circ} \mathrm{C}$ for $12 \mathrm{sec}, 55{ }^{\circ} \mathrm{C}$ for 90 sec and $72{ }^{\circ} \mathrm{C}$ for $20 \mathrm{sec}$. Probe emission signals were acquired during the $20 \mathrm{sec}$ extension step of the cycling programme. The relatively long 90 second annealing step was found to improve the sensitivity of the multiple primer and probe real-time PCR assay (data not shown).

The singleplex real-time PCR assays used in the sensitivity comparison with the tandem multiplex real-time assays were performed as for the enrichment PCR assays described above, except that the only a single primer pair and the appropriate fluorophore-labelled oligonucleotide probe $(0.2 \mu \mathrm{M})$ were included in the PCR reaction mix. The number of cycles was increased to 50, the denaturation, annealing and extension steps were reduced to 10, 15 and 15 secs, respectively, and performed on the Corbett RG6000 thermocycler (Corbett Life Science, Australia).

The nested PCR assays used in the sensitivity comparison assays are mostly "in-house-modified" assays and have been used in our diagnostic laboratory for many years. Since they are slowly being superseded by real-time amplification assays, the primer sequences have not been listed in this article but are available on application to the authors. Briefly, the nested assays used $8 \mu \mathrm{L}$ of nucleic acid sample in a $20 \mu \mathrm{L}$ reaction volume in the Superscript III Platinum One-step RT-PCR (Invitrogen, USA) or the Amplitaq Gold DNA polymerase system (Applied Biosystems, USA). Appropriate enzyme activation was followed by 45 cycles of $95^{\circ} \mathrm{C}$ for $30 \mathrm{sec}, 50{ }^{\circ} \mathrm{C}$ for $30 \mathrm{sec}$ and $72{ }^{\circ} \mathrm{C}$ for 45 sec. Similar conditions were used for the second PCR assay with $0.5 \mu \mathrm{L}$ of the initial PCR product as the target DNA. Amplicons were detected by ethidium bromide agarose gel electrophoresis.

The picornavirus and human metapneumoviruses were detected using traditional semi-nested PCR assays as we have not yet been able to design real-time PCR assays to reliably detect all strains of those viruses. The picornavirus PCR utilized published primer sets targeting the 5' untranslated region of the virus genome $[45,46]$ and enterovirus or rhinovirus identification was confirmed by DNA sequencing. The in-house human metapneumovirus assay targets the matrix protein gene of the virus.

Well characterized DNA and RNA control materials were tested in traditional nested PCR assays, individual real-time assays and in the multiplex tandem real-time PCR assay.

A collection of 121 respiratory samples from hospitalized children was tested in the multiplex tandem real-time assay. The samples were received at the PathWest Laboratory Medicine WA facility for the routine investigation of respiratory infection and had previously been tested for a narrow range of respiratory pathogens. Samples had been stored at $-20^{\circ} \mathrm{C}$. 
No-template controls were included in the extraction process between every five samples and treated as samples for the completion of the assays. Since all PCR mixes were quality checked for all agents prior to use, and the internal controls cover the extraction, inhibitor removal and cDNA production processes, specific positive control materials were only included in the real-time Taqman PCR assays. Those control materials were well-characterized enrichment PCR products stored in aliquots at $-20^{\circ} \mathrm{C}$.

\section{Conclusions}

A tandem multiplex real-time assay is presented which detects a comprehensive range of respiratory pathogens from a specimen sample of $180 \mu \mathrm{L}$. The initial enrichment PCR eliminates the requirement for individual reverse transcription steps for each of the RNA viruses, resulting in considerable cost and specimen volume benefits. The secondary multiplex real-time PCR utilizes probes labeled with different fluorophores to facilitate a rapid result.

The technique may be used in the routine diagnostic setting or in an outbreak or pandemic situation, to facilitate testing for a range of common, exotic and emerging pathogens. Extra primers and probes for novel agents may be easily accommodated in this technique.

\section{References}

1. van der Hoek, L.; Pyrc, K.; Jebbink, M.F.; Vermeulen-Oost, W.; Berkhout, R.J.M.; Wolthers, K.C.; Wertheim-van Dillen, P.M.E.; Kaandorp, J.; Spaargaren, J.; Berkhout, B. Identification of a new human coronavirus. Nat. Med. 2004, 10, 368-373.

2. Woo, P.C.Y.; Lau, S.K.P.; Chu, C.M.; Chan, K.H.; Tsoi, H.W.; Huang, Y.; Wong, B.H.L.; Poon, R.W.S.; Cai, J.J.; Luk, W.K.; Poon, L.L.M.; Wong, S.S.Y.; Guan, Y.; Peiris, J.S.M.; Yuen, K.Y. Characterization and complete genome sequence of a novel coronavirus, coronavirus HKU1, from patients with pneumonia. J. Virol. 2005, 79, 884-895.

3. Drosten, C.; Gunther, S.; Preiser, W.; van der Werf, S.; Brodt, H.R.; Becker, S.; Rabenau, H.; Panning, M.; Kolesnikova, L.; Fouchier, R.A.M.; Berger, A.; Burguiere, A.M.; Cinatl, J.; Eickmann, M.; Escriou, N.; Grywna, K.; Kramme, S.; Manuguerra, J.C.; Muller, S.; Rickerts, V.; Sturmer, M.; Vieth, S.; Klenk, H.D.; Osterhaus, A.D.M.E.; Schmitz, H.; Doerr, H.W. Identification of a novel coronavirus in patients with severe acute respiratory syndrome. $N$. Engl. J. Med. 2003, 348, 1967-1976.

4. van den Hoogen, B.G.; de Jong, J.C.; Groen, J.; Kuiken, T.; de Groot, R.; Fouchier, R.A.M.; Osterhaus, A.D.M.E. A newly discovered human pneumovirus isolated from young children with respiratory tract disease. Nat. Med. 2001, 7, 719-724.

5. Allander, T.; Tammi, M.; Eriksson, M.; Bjerkner, A.; Tivel-Lindell, A. Cloning of a human parvovirus by molecular screening of respiratory tract samples. Proc. Natl Acad. Sci. USA 2005, 102, 12891-12896.

6. Allander, T.; Andreasson, K.; Gupta, S.; Bjerkner, A.; Bogdanovic, G.; Persson, M.A.A.; Dalianis, T.; Ramqvist, T.; Andersson, B. Identification of a third human polyomavirus. J. Virol. 2007, 81, 4130-4136. 
7. Gaynor, A.M.; Nissen, M.D.; Whiley, D.M.; Mackay, I.M.; Lambert, S.B.; Guang, W.; Brennan, D.C.; Storch, G.A.; Sloots, T.P.; Wang, D. Identification of a novel polyomavirus from patients with acute respiratory tract infections. PLoS Pathog. 2007, 3, e64.

8. Arden K.E.; McErlean P.; Nissen M.D.; Sloots T.P.; Mackay, I.M. Frequent detection of human rhinoviruses, paramyxoviruses, coronaviruses, and bocavirus during acute respiratory tract infections. J. Med. Virol. 2006, 78, 1232-1240.

9. Templeton, K.E.; Scheltinga, S.A.; van den Eeden, W.C.J.F.M.; Graffelman, A.W.; van den Broek, P.J.; Claas, E.C.J. Improved diagnosis of the etiology of community-acquired pneumonia with real-time polymerase chain reaction. Clin. Infect. Dis. 2005, 41, 345-351.

10. Stanley, K.K. Szewczuk, E. Multiplexed tandem PCR: gene profiling from small amounts of RNA using SYBR Green detection. Nucl. Acids Res. 2005, 33, e180.

11. Allard, A.; Albinsson, B.; Wadell, G. Detection of adenoviruses in stools from healthy persons and patients with diarrhea by two-step polymerase chain reaction. J. Med. Virol. 1992, 37, 149157.

12. Backman, A.; Johansson, B.; Olcen, P. Nested PCR optimized for detection of Bordetella pertussis in clinical nasopharyngeal samples. J. Clin. Microbiol. 1994, 32, 2544-2548.

13. Messmer, T.O.; Skelton, S.K.; Moroney, J.F.; Daugharty, H.; Fields, B.S. Application of a nested, multiplex PCR to psittacosis outbreaks. J. Clin. Microbiol. 1997, 35, 2043-2046.

14. Myint, S.; Johnston, S.; Sanderson, G.; Simpson, H. Evaluation of nested polymerase chain methods for the detection of human coronaviruses 229E and OC43. Mol Cell Probes. 1994, 8, 357-364.

15. Zhang, W.; Evans, D.H. PCR detection and differentiation of influenza viruses A, B, and C strains. In Diagnostic Molecular Microbiology, Principles and Applications; Persing, D.H., Smith, T.F., Tenover, F.C., White, T.J., Eds.; ASM Press: Washington, DC, USA, 1993; pp. 374382.

16. Lindsay, D.S.; Abraham, W.H.; Fallon, R.J. Detection of mip gene by PCR for diagnosis of Legionnaires' disease. J. Clin. Microbiol. 1994, 32, 3068-3069.

17. Williamson, J.; Marmion, B.P.; Worswick, D.A.; Kok, T.W.; Tannock, G.; Herd, R.; Harris, R.J. Laboratory diagnosis of Mycoplasma pneumoniae infection. 4. Antigen capture and PCR-gene amplification for detection of the Mycoplasma: Problems of clinical correlation. Epidem. Infect. 1992, 109, 519-537.

18. Echevarria, J.E.; Erdman, D.D.; Swierkosz, E.M.; Holloway, B.P.; Anderson, L.J. Simultaneous detection and identification of human parainfluenza viruses 1, 2, and 3 from clinical samples by multiplex PCR. J. Clin. Microbiol. 1998, 36, 1388-1391.

19. Evans, R.; Joss, A.W.L.; Pennington, T.H.; Ho-Yen, D.O. The use of a nested polymerase chain reaction for detecting Pneumocystis carinii from lung and blood in rat and human infection. $J$. Med. Microbiol. 1995, 42, 209-213.

20. Cubie, H.A.; Inglis, J.M.; Leslie, E.E.; Edmunds, A.T.; Totapally, B. Detection of respiratory syncytial virus in acute bronchiolitis in infants. J. Med. Virol. 1992, 38, 283-287.

21. Gunnarsson, R.K.; Holm, S.E.; Söderström, M. The prevalence of potential pathogenic bacteria in nasopharyngeal samples from healthy children and adults. Scand. J. Prim. Health Care. 1998, 16, 13-17. 
22. Kumar, S.; Wang, L.; Fan, J.; Kraft, A.; Bose, M.E.; Tiwari, S.; Van Dyke, M.; Haigis, R.; Luo, T.; Ghosh, M.; Tang, H.; Haghnia, M.; Mather, E.L.; Weisburg, W.G.; Henrickson, K.J. Detection of 11 common viral and bacterial pathogens causing community-acquired pneumonia or sepsis in asymptomatic patients by using a multiplex reverse transcription-PCR assay with manual (enzyme hybridization) or automated (electronic microarray) detection. J. Clin. Microbiol. 2008, 46, 3063-3072.

23. Pettigrew, M.M.; Gent, J.F.; Revai, K.; Patel, J.A.; Chonmaitree, T. Microbial interactions during upper respiratory tract infections. Emerg. Infect. Dis. 2008, 14, 1584-1591.

24. Bialasiewicz, S.; Whiley, D.M.; Lambert, S.B.; Jacob, K.; Bletchly, C.; Wang, D.; Nissen, M.D.; Sloots, T.P. Presence of the newly discovered human polyomaviruses KI and WU in Australian patients with acute respiratory tract infection. J. Clin. Virol. 2008, 41, 63-68.

25. Norja, P.; Ubillos, I.; Templeton, K.; Simmonds, P. No evidence for an association between infections with WU and KI polyomaviruses and respiratory disease. J. Clin. Virol. 2007, 40, 307311.

26. Lam, W.Y.; Yeung, A.C.M.; Tang, J.W.; Ip, M.; Chan, E.W.C.; Hui, M.; Chan, P.K.S. Rapid multiplex nested PCR for detection of respiratory viruses. J. Clin. Microbiol. 2007, 45, 36313640.

27. Pierangeli, A.; Gentile, M.; Di Marco, P.; Pagnotti, P.; Scagnolari, C.; Trombetti, S.; Lo Russo, L.; Tromba, V.; Moretti, C.; Midulla, F.; Antonelli, G. Detection and typing by molecular techniques of respiratory viruses in children hospitalized for acute respiratory infection in Rome, Italy. J. Med. Virol. 2007, 79, 463-468.

28. Freymuth, F.; Vabret, A.; Cuvillon-Nimal, D.; Simon, S.; Dina, J.; Legrand, L.; Gouarin, S.; Petitjean, J.; Eckart, P.; Brouard, J. Comparison of multiplex PCR assays and conventional techniques for the diagnostic of respiratory virus infections in children admitted to hospital with an acute respiratory illness. J. Med. Virol. 2006, 78, 1498-1504.

29. Semple, M.G.; Cowell, A.; Dove, W.; Greensill, J.; McNamara, P.S.; Halfhide, C.; Shears, P.; Smyth, R.L.; Hart, C.A. Dual infection of infants by human metapneumovirus and human respiratory syncytial virus is strongly associated with severe bronchiolitis. J. Infect. Dis. 2005, 191, 382-386.

30. Papadopoulos, N.G.; Moustaki, M.; Tsolia, M.; Bossios, A.; Astra, E.; Prezerakou, A.; Gourgiotis, D.; Kafetzis, D. Association of rhinovirus infection with increased disease severity in acute bronchiolitis. Am. J. Respir. Crit. Care Med. 2002, 165, 1285-1289.

31. Andréoletti, L.; Lesay, M.; Deschildre, A.; Lambert, V.; Dewilde, A.; Wattré, P. Differential detection of rhinoviruses and enteroviruses RNA sequences associated with classical immunofluorescence assay detection of respiratory virus antigens in nasopharyngeal swabs from infants with bronchiolitis. J. Med. Virol. 2000, 61, 341-346.

32. van Doorn, L.J.; Molijn, A.; Kleter, B.; Quint, W.; Colau, B. Highly effective detection of human papillomavirus 16 and 18 DNA by a testing algorithm combining broad-spectrum and typespecific PCR. J. Clin. Microbiol. 2006, 44, 3292-3298.

33. Grondahl, B.; Puppe, W.; Hoppe, A.; Kuhne, I.; Weigl, J.A.I.; Schmitt, H.J. Rapid identification of nine microorganisms causing acute respiratory tract infections by single-tube multiplex reverse transcription-PCR: Feasibility study. J. Clin. Microbiol. 1999, 37, 1-7. 
34. Coiras, M.T.; Aguilar, J.C.; García, M.L.; Casas, I.; Pérez-Breña, P. Simultaneous detection of fourteen respiratory viruses in clinical specimens by two multiplex reverse transcription nestedPCR assays. J. Med. Virol. 2004, 72, 484-495.

35. Reijans, M.; Dingemans, G.; Klaassen, C.H.; Meis, J.F.; Keijdener, J.; Mulders, B.; Eadie, K.; van Leeuwen, W.; van Belkum, A.; Horrevorts, A.M.; Simons, G. RespiFinder: a new multiparameter test to differentially identify fifteen respiratory viruses. J. Clin. Microbiol. 2008, 46, 1232-1240.

36. Lee, W.M.; Grindle, K.; Pappas, T.; Marshall, D.J.; Moser, M.J.; Beaty, E.L.; Shult, P.A.; Prudent, J.R.; Gern, J.E. High-throughput, sensitive, and accurate multiplex PCR-Microsphere flow cytometry system for large-scale comprehensive detection of respiratory viruses. J. Clin. Microbiol. 2007, 45, 2626-2634.

37. Boivin, G.; Cote, S.; Dery, P.; De Serres, G.; Bergeron, M.G. Multiplex real-time PCR assay for detection of Influenza and human respiratory syncytial viruses. J. Clin. Microbiol. 2004, 42, 4551.

38. Gunson, R.N.; Collins, T.C.; Carman, W.F. Real-time RT-PCR detection of 12 respiratory viral infections in four triplex reactions. J. Clin. Virol. 2005, 33, 341-344.

39. Templeton, K.E.; Scheltinga, S.A.; Beersma, M.F.C.; Kroes, A.C.M.; Claas, E.C.J. Rapid and sensitive method using multiplex real-time PCR for diagnosis of infections by influenza $A$ and influenza B viruses, respiratory syncytial virus, and parainfluenza viruses 1 , 2, 3, and 4. J. Clin. Microbiol. 2004, 42, 1564-1569.

40. Lau, S.K.P.; Yip, C.C.Y.; Tsoi, H.W.; Lee, R.A.; So, L.Y.; Lau, Y.L.; Chan, K.H.; Woo, P.C.Y.; Yuen, K.Y. Clinical features and complete genome characterization of a distinct human rhinovirus (HRV) genetic cluster, probably representing a previously undetected HRV species, HRV-C, associated with acute respiratory illness in children. J. Clin. Microbiol. 2007, 45, 36553664.

41. Lee, W.M.; Kiesner, C.; Pappas, T.; Lee, I.; Grindle, K.; Jartti, T.; Jakiela, B.; Lemanske, R.F., Jr.; Shult, P.A.; Gern, J.E. A diverse group of previously unrecognized human rhinoviruses are common causes of respiratory illnesses in infants. PLoS ONE. 2007, 2, e966.

42. Druce, J.; Catton, M.; Chibo, D.; Minerds, K.; Tyssen, D.; Kostecki, R.; Maskill, B.; LeongShaw, W.; Gerrard, M.; Birch, C. Utility of a multiplex PCR assay for detecting herpesvirus DNA in clinical samples. J. Clin. Microbiol. 2002, 40, 1728-1732.

43. Dreier, J.; Stormer, M.; Made, D.; Burkhardt, S.; Kleesiek, K. Enhanced reverse transcriptionPCR assay for detection of norovirus genogroup I. J. Clin. Microbiol. 2006, 44, 2714-2720.

44. Whiley, D.M. Sloots, T.P. A 5'-nuclease real-time reverse transcriptase-polymerase chain reaction assay for the detection of a broad range of influenza A subtypes, including H5N1. Diagn. Microbiol. Infect. Dis. 2005, 53, 335-337.

45. Ireland, D.C.; Kent, J.; Nicholson, K.G. Improved detection of rhinoviruses in nasal and throat swabs by seminested RT-PCR. J. Med. Virol. 1993, 40, 96-101.

46. Hyypia, T.; Auvinen, P.; Maaronen, M. Polymerase chain reaction for human picornaviruses. $J$. Gen. Virol. 1989, 70, 3261-3268.

(C) 2009 by the authors; licensee Molecular Diversity Preservation International, Basel, Switzerland. This article is an open-access article distributed under the terms and conditions of the Creative Commons Attribution license (http://creativecommons.org/licenses/by/3.0/). 